\title{
Pengaruh Beban Kerja, Stres Kerja dan Lingkungan Kerja Terhadap Kinerja Guru Madrasah Aliyah Negeri 2 Kota Palu
}

\author{
Abdul Jali1 ${ }^{1 *}$ \\ ${ }^{1}$ Jurusan Perbankan Syariah, Fakultas Ekonomi dan Bisnis Islam, IAIN Palu
}

Penelitian ini adalah : (1) Untuk mengetahui dan menganalisis pengaruh beban kerja, stress kerja dan lingkungan kerja secara simultan terhadap kinerja guru MAN 2 Kota palu : (2) Untuk mengetahui dan menganalisis pengaruh beban kerja secara parsial terhadap kinerja guru MAN 2 Kota Palu : (3) Untuk mengetahui dan menganalisis pengaruh stres kerja secara parsial terhadap kinerja guru MAN 2 Kota Palu : (4) Untuk mengetahui dan menganalisis pengaruh lingkungan kerja secara parsial terhadap kinerja guru MAN 2 Kota Palu. Sampel penelitian sebanyak 55 orang guru MAN 2 Kota Palu dengan menggunakan sampel jenuh (sensus), dimana dalam teknik ini semua anggota populasi mendapat peluang untuk dijadikan sampel (Sugiyono, 2008:116). Jenis penelitian ini adalah deskriptif kausal dengan teknik analisis data menggunakan analisis regresi linear berganda. Hasil penelitian menunjukkan bahwa variabel beban kerja, stress kerja dan lingkungan kerja secara simultan berpengaruh signifikan terhadap kinerja guru Man 2 Kota Palu, dengan nilai sig-F sebesar $0,00<\alpha 0,05$. Variabel beban kerja berpengaruh negatif dan signifikan terhadap kinerja guru dengan nilai Sig-t 0,025; stress berpengaruh positif dan signifikan terhadap kinerja guru dengan nilai Sig-t 0,013 dan budaya kerja berpengaruh positif dan signifikan terhadap kinerja guru dengan nilai Sig-t 0,032.

\author{
Katakunci: \\ Beban Kerja, Stres \\ Kerja, Lingkungan \\ Kerja, Kinerja Guru
}




\section{PENDAHULUAN}

Proses pendidikan merupakan sebuah proses yang dilakukan dengan sengaja yang bertujuan untuk mencerdasakan kehidupan bangsa, melalui proses pendidikan yang dapat membentuk sosok individu sebagai sumber daya manusia yang akan berperan besar dalam proses pembanguna bangsa dan negara. Peran pendidikan sangat penting sebab pendidikan merupakan kunci utama untuk menciptakan sumber daya manusia yang berkualitas.

Guru merupakan elemen kunci dalam sistem pendidikan, khususnya disekolah. Semua komponen lain mulai dari kurikulum, sarana dan prasarana, biaya dan sebagainya tidak akan banyak berarti apabilan pembelajaran yaitu interaksi guru dengan siswa tidak berkualitas. Begitu pentingnya peran guru dalam mentransformasikan inputinput pendidikan sehingga para pakar menyatakan disekolah tidak aka ada perubahan atau peningkatan kualitas tanpa adanya perubahan dan peningkatan kualitas guru.Berdasarkan pendapat diatas maka penilaian kinerja guru merupakan suatu hal yang perlu mendapat perhatian.

Undang-undang Nomor 20 tahun 2003 menyebutkan bahwa pendidikan nasional berfungsi mengembangkan kemapuan dan membentuk watak serta peradaban bangsa yang bermartabat dalam rangka mencerdaskan kehidupan bangsa, bertujuan untuk berkembangnya potensi peserta didik agar menjadi manusia yang beriman dan bertaqwa kepada Tuhan Yang Maha Esa, berakhlak mulia, sehat, berilmu, cakap, kreatif dan menjadi warga Negara yang demokratis dan bertanggung jawab.

Undang-undang Nomor 14 Tahun 2005 tentang Guru dan Dosen pasal 10 menjelaskan bahwa guru wajib memiliki kompetensi. Kompetensi yang dimaksud dalam pasal tersebut yaitu kompetensi pedagogik, kompetensi kepribadian, kompetensi social, kompetensi profesional dan pasal 20 butir a menjelaskan bahwa dalam melaksanakan tugas keprofesionalannya, guru berkewajiban merencanakan pembelajaran, melaksanakan proses pembelajaran yang bermutu serta menilai dan mengevaluasi hasil pembelajaran.

Dengan memberikan beban kerja yang efektif instansi pemerintahan dapat mengetahui sejauh mana guru dapat diberikan beban kerja yang maksimal dan sejauh mana pengaruhnya terhadap kinerja instansi itu sendiri.Guru yang tidak disiplin dalam memanfaatkan waktu kerja akan berdampak pada beban kerja yang menumpuk, sehingga membutuhkan waktu yang lebih dari waktu kerja normal yang ditentukan untuk menyelesaikan tugas yang dibebankan. Permendagri No. 12/2008 menyatakan bahwa beban kerja adalah 
besaran pekerjaan yang harus dipikul oleh suatu jabatan/unit organisasi dan merupakan hasil kali antara volume kerja dan norma waktu. Jika kemampuan pekerja lebih tinggi dari pada tuntutan pekerjaan, akan muncul perasaan bosan. Namun sebaliknya, jika kemampuan pekerja lebih rendah dari pada tuntutan pekerjaan, maka, akan muncul kelelahan yang lebih. Oleh karena itu, pembagian beban kerja yang tepat dan sesuai dengan kemampuan guru sangat perlu diperhatikan karena dapat mempengaruhi kinerja dan juga pencapaian dari Instansi itu sendiri.

Selain beban kerja, faktor lain yang mempengaruhi kinerja guru adalah stress kerja. Stress merupakan suatu kondisi seseorang yang mengalami ketegangan karena adanya kondisi yang mempengaruhinya, kondisi tersebut dapat diperoleh dari dalam diri seseorang maupun lingkungan diluar diri seseorang. Stress dapat menimbulkan dampak yang negatif terhadap keadaan psikologis dan biologis bagi guru itu sendiri. Menurut Siagian (2009:2003) stress merupakan kondisi ketegangan yang berpengaruh terhadap emosi, jalan pikiran dan kondisi fisik seseorang. Stress yang tidak dapat diatasi dengan baik biasanya berakibat pada ketidak mampuan seseorang berinteraksi dengan lingkungan, baik lingkungan pekerjaan maupun diluar pekerjaan.
Penelitian ini dilakukan pada Madrasah Aliyah Negeri 2 Kota Palu.Sehubungan dengan kondisi riil serta diperkuat oleh konsep teori tersebut diatas, maka penulis memfokuskan pengamatan tentang pengaruh beban kerja, stres kerja dan lingkungan kerja terhadap kinerja guru pada Madrasah Aliyah Negeri 2 Kota Palu.Melalui hasil wawancara kepada Kepala Tata Usaha yang berinisial S, dia menjelaskan kondisi dan permasalahan terhadap gurupada Madrasah Aliyah Negeri 2 Kota Palu. Beliau menjelaskan sekitar 20\% kinerja guru belum maksimal. Hal ini mungkin disebabkan oleh beban kerja yang tidak seimbang atau tidak sama meskipun dengan jenis pekerjaan yang sama. Beliau juga menjelaskan ketidak meratanya beban kerja antara tenaga pendidik yang satu dengan yang lainnya sehingga sering menimbulkan kecemburuan sosial antar guru tersebut.Dalam bekerja juga karena ketidak disiplinan rekan kerja sehingga tidak jarang seorang guru kelas harus mengawasi 2 kelas sekaligus dalam waktu bersamaan, hal ini tentunya berdampak pada meningkatnya beban kerja seorang guru karena harus juga mengisi kekosongan dikelas lain.Besarnya target kerja yang diberikan untuk menyelesaikan pekerjaannya, begitu pula dengan hasil kerja yang harus diselesaikan dalam jangka waktu tertentu, serta mengatasi kejadian yang tak terduga seperti melakukan 
pekerjaan ekstra diluar waktu yang telah ditentukan.

Beberapa guru pernah didapatkan berselisih dengan guru lainnya terkait pekerjaan disekolah. Hal ini menunjukkan hubungan antar guru yang dimaksud masih belum baik sedangkan hubungan antara atasan dengan bawahan sudah cukup baik (sumber : kepala tata usaha). Terkait dengan stres kerja guru stres dalam bekerja dikarenakan adanya teman/rekan kerja yang sering emosi tanpa sebab, terkadang pula ucapannya sering menyinggung perasaan sehingga menyebabkan terganggunya konsentrasi pada saat bekerja. Kecenderungan lain dalam bekerja guru sering menyaksikan sesama guru lain kurang akur, saling menjelekkan satu sama lain dan ada juga guru yang diberikan tanggung jawab untuk menyelesaikan pekerjaannya tetapi tidak diselesaikan sehingga pekerjaan itu dilimpahkan keguru yang lain.Kemudian adanya masalah pribadi yang sumber masalahnya berasal dari rumah seperti masalah keluarga, hutang, biaya pendidikan dan kebutuhan anak-anak yang banyak (sumber: dewan guru).

Sikap pimpinan yang diskriminatif dan cenderung arogan dalam melaksanakan tugas dapat juga memberikan efek yang tidak baik terhadap psikologi bawahan sehingga menyebabkan stress dalam bekerja serta mereka merasa terkucilkan dan merasa tertekan karena arogansi dari atasan. Hal lain seperti seeringnya terjadi pertentang antar sesama guru dalam kesehariannya juga dapat mempengaruhi kinerja. Kurangnya rasa kekeluaragaan dalam lingkungan sekolah mengakibatkan keharmonisan sering terusik karena tidak ada kerja sama yang kurang baik dari individu didalamnya sehingga bisa mengakibatkan rendahnya semangat dalam bekerja dan otomatis berdampak langsung pada kinerja (sumber: dewan guru).

Terkait dengan lingkungan kerja disekolah, terdapat beberapa lingkungan kerja yang kurang baik. Hal ini ditandai dengan ketidaknyamanan dalam bekerja, ruang kerja yang tidak nyaman dengan tata ruang yang kurang baik, ruang gerak yang sempit dan sesak, fasilitas pendingin udara yang kurang memadai sehingga membuat guru tidak nyaman dalam bekerja (sumber: dewan guru).

\section{TINJAUAN PUSTAKA}

Beban Kerja

Menurut Dhini Rama Dhania (2010:16) beban kerja adalah sekumpulan atau sejumlah kegiatan yang harus diselesaikan oleh suatu unit organisasi atau pemegang jabatan dalam jangka waktu tertentu. Sementara Komaruddin (1996:235) mengemukakan bahwa analisa beban kerja adalah proses untuk menetapkan jumlah jam kerja orang yang digunakan atau dibutuhkan 
untuk merampungkan suatu pekerjaan dalam waktu tertentu, atau dengan kata lain analisis beban kerja bertujuan untuk menentukan berapa jumlah personalia dan beberapa jumlah tanggung jawab atau beban kerja yang tepat dilimpahkan kepada seortang petugas. Sedangkan menurut Permendagri No. 12/2008, beban kerja adalah besaran pekerjaan yang harus dipikul oleh suatu jabatan atau unit organisasi dan merupakan hasil kali antara volume kerja dan norma waktu.

Robbins (2003:90) menyatakan bahwa positif negatifnya beban kerja merupakan masalah persepsi. Persepsi didefinisikan sebagai suatu proses dimana individu mengorganisasikan dan menafsirkan kesan indera meraka agar memberi makna kepada lingkungan mereka (Robbins, 2007:160). Persepsi terhadap beban kerja berkaitan dengan faktor atribut peran dan pekerjaan.

Hal ini dikarenakan persepsi terhadap beban kerja merupakan hal yang erat hubungannya dengan suatu pekerjaan, dimana individu memberikan penilaian mengenai sejumlah tuntutan tugas atau kegiatan yang membutuhkan aktivitas mental dan fisik yang harus ia selesaikan dalam waktu tertentu, apakah memiliki dampak positif atau negatif terhadap pekerjaannya.
Indikator beban kerja yang dikemukakan dalam jurnal Putra (2012:22), yang meliputi antara lain :

1) Target yang harus dicapai

Pandangan individu mengenai besarnya target kerja yang diberikan untuk menyelesaikan pekerjaannya, misalnya untuk menggiling, melinting, mengepak dan mengangkut. Pandangan mengenai hasil kerja yang harus diselesaikan dalam jangka waktu tertentu.

2) Kondisi Pekerjaan

Mencakup tentang bagaimana pandangan yang dimiliki oleh individu mengenai kondisi pekerjaannya, misalnya mengambil keputusan dengan cepat pada saat pengerjaan barang, serta mengatasi kejadian yang tak terduga seperti melakukan pekerjaan ekstra diluar waktu yang telah ditentukan.

3) Standar Pekerjaan

Kesan yang dimiliki oleh individu mengenai pekerjaannya, misalnya perasaan yang timbul mengenai beban kerja yang harus diselesaikan dalam jangka waktu tertentu.

\section{Stres Kerja}

Stres kerja adalah konsekuensi setiap tindakan dan situasi lingkungan yang menimbulkan tuntutan psikologis dan fisik yang berlebihan pada seseorang. Cartwright dan Cooper (1994) dalam Mangkunegara 
(2008:179) mengemukakan stres kerja sebagai suatu ketegangan atau tekanan yang dialami ketika tuntutan yang dihadapkan melebihi kekuatan yang ada pada diri kita.

Menurut Robbins

$(2008: 793)$ menyatakan stress adalah kondisi dinamik yang didalamnya individu menghadapi peluang, kendala atau tuntutan yang terkait dengan apa yang sangat diinginkan dan hasilnya dipersepsikan sebagai tidak pasti tetapi penting. Sedangkan menurut Effendi (2002:157) dalam mengemukakan bahwa stres kerja adalah ketegangan atau tekanan emosional yang dialami seseorang yang sedang menghadapi tuntutan yang sangat besar, hambatan-hambatan dan adanya kesempatan yang sangat penting yang dapat mempengaruhi emosi, pikiran, dan kondisi fisik seseorang.

Adapun menurut Siagian (2008:300) menyatakan bahwa stres merupakan kondisi ketegangan yang berpengaruh terhadap emosi, jalan pikiran, dan kondisi fisik seseorang.Stres yang tidak bisa diatasi dengan baik biasanya berakibat pada ketidak mampuan orang berinteraksi secara positif dengan lingkungannya, baik dalam lingkungan pekerjaan maupun lingkungan luarnya. Artinya, pegawai yang bersangkutan akan menghadapi berbagai gejala negatif yang pada gilirannya berpengaruh pada prestasi kerja
Selanjutnya Mangkunegara (2008:157) mengemukakan bahwa stres kerja sebagai perasaan yang menekan atau merasa tertekan yang dialami pegawai dalam menghadapi pekerjaan.Stres kerja adalah suatu kondisi ketegangan yang menciptakan adanya ketidakseimbangan fisik dan psikis, yang mempengaruhi emosi, proses berpikir, dan kondisi seorang pegawai. Stres yang terlalu besar dapat mengancam kemampuan seseorang untuk menghadapi lingkungan. Sebagai hasilnya, pada diri para pegawai berkembang berbagai macam gejala stres yang dapat mengganggu pelaksanaan kerja mereka (Rivai, 2008:516).

Adapun menurut Robbins (2006, 796-797) dia mengutarakan bahwa ada 5 indikator stres kerja, yaitu :

1) Tuntutan tugas, merupakan faktor yang dikaitkan pada pekerjaan seseorang seperti kondisi kerja, tata kerja letak fisik.

2) Tuntutan peran, berhubungan dengan tekanan yang diberikan pada seseorang sebagai suatu fungsi dari peran tertentu yang dikerjakan dalam suatu organisasi.

3) Tuntutan antar pribadi, merupakan tekanan yang diciptakan oleh pegawai lain.

4) Struktur organisasi, gambaran instansi yang diwarnai dengan struktur organisasi yang tidak jelas, kurangnya penjelasan mengenai jabatan, peran, wewenang dan tanggung jawab. 
5) Kepemimpinan, beberapa pihak selaku pimpinan dalam gaya manajemen pada organisasi dapat membuat iklim organisasi yang melibatkan ketegangan, ketakutan dan kecemasan.

\section{Lingkungan Kerja}

Lingkungan kerja banyak didefinisikan oleh para ahli, beberapa diantaranya adalah sebagai berikut :

1. Nitisemito (2002;11), lingkungan kerja adalah sesuatu yang ada disekitar para pekerja dan yang mempengaruhi dirinya dalam menjalankan tugas-tugas yang dibebankan.

2. Sedarmayati (2001;21), menyatakan lingkungan kerja sebagai keseluruhan alat perkakas dan bahan yang dihadapi, lingkungan sekitarnya di mana seseorang bekerja, metode kerjanya, serta pengaturan kerjanya baik sebagai perseorangan maupun sebagai kelompok.

3. Swastha dan Sukotjo (2004:26-27), menyatakan lingkungan perusahaan dapat diartikan sebagai keseluruhan dari faktorfaktor ekstern yang mempengaruhi baik organisasi maupun kegiatannya. Sedangkan arti lingkungan kerja secara luas mencakup semua faktorfaktor ekstern yang mempengaruhi individu, perusahaan, dan masyarakat.

4. Heijrachman dan Husnan (1997:34), menyatakan bahwa yang 3 dimaksud dengan pengaturan lingkungan kerja adalah pengaturan penerangan tempat kerja, pengontrolan terhadap suara gaduh dalam pabrik, pengontrolan terhadap udara, pengaturan kebersihan tempat kerja, dan pengaturan tentang keamanan kerja.

Menurut Sumamur dalam penelitian Nasution dan Rodhiah (Jurnal Manajemen, 2008:59), mengemukakan bahwa ada tiga faktor yang mempengaruhi lingkungan kerja, yaitu :

1) Fasilitas Kerja. Lingkungan yang kurang mendukung pelaksanaan kerja ikut menyebabkan kinerja yang kurang, seperti kurangnya alat kerja, ruang kerja yang pengap, ventilasi yang kurang serta prosedur yang tidak jelas.

2) Gaji dan tunjangan. Gaji yang tidak sesuai dengan harapan pekerjaan membuat pekerja setiap saat melirik ke lingkungan kerja yang lebih menjamin pencapaian harapan kerja.

3) Hubungan kerja. Kelompok kerja yang menampakkan loyalitas yang tinggi akan meningkatkan produktivitas kerja karena satu pekerjaan dengan pekerjaan yang lain akan saling mendukung pencapaian tujuan dan atau hasil.

Faktor-faktor yang dapat mempengaruhi terbentuknya suatu kondisi lingkungan kerja fisik menurut Nitisemito (1992;159) adalah sebagai berikut: 
1) Pewarnaan

Masalah warna dapat berpengaruh terhadap pelaksanaan pekerjaan, akan tetapi banyak instansi yang kurang memperhatikan masalah warna. Dengan demikian pengaturan hendaknya memberi manfaat, sehingga dapat meningkatkan semangat kerja.Pewarnaan pada dinding ruang kerja hendaknya mempergunakan warna yang lembut.

2) Penerangan

Penerangan dalam ruang kerja memegang peranan yang sangat penting dalam meningkatkan semangat karyawan sehingga mereka akan dapat menunjukkan hasil kerja yang baik, yang berarti bahwa penerangan tempat kerja yang cukup sangat membantu berhasilnya kegiatan-kegiatan operasional organisasi.

3) Udara

Di dalam ruangan kerja dibutuhkan udara yang cukup, dimana dengan adanya pertukaran udara yang cukup, akan menyebabkan kesegaran fisik dari gurutersebut. Suhu udara yang terlalu panas akan menurunkan semangat kerja di dalam melaksanakan pekerjaan.

4) Suara Bising

Suara yang bunyi bisa sangat menganggu dalam bekerja.Suara bising tersebut dapat merusak konsentrasi kerja sehingga kinerja bisa menjadi tidak optimal.Oleh karena itu setiap organisasiatau instansi harus selalu berusaha untuk menghilangkan suara bising tersebut atau paling tidak menekannya untuk memperkecil suara bising tersebut.

5) Ruang Gerak

Pada suatu Instansi sebaiknya dalam bekerja mendapat fasilitas tempat yang cukup untuk melaksanakan pekerjaan atau tugas.Guru tidak mungkin dapat bekerja dengan tenang dan maksimal jika tempat yang tersedia tidak dapat memberikan kenyamanan. Dengan demikian ruang gerak untuk tempat bekerja seharusnya direncanakan terlebih dahulu agar para karyawan tidak terganggu di dalam melaksanakan pekerjaan. Menurut Assauri (1993:33) mengemukakan bahwa: "Agar para pegawai dapat leluasa bergerak dengan baik, maka ruangan gerak para pegawai perlu diberikan ruangan yang memadai. Terlalu sempit ruang gerak akan menghambat proses kerja para pegawai. Sebaliknya ruangan kerja yang besar merupakan pemborosan ruangan.

Dari pendapat di atas mengenai ruang gerak yang ideal adalah ruang yang leluasa sehingga dapat membantu kelancaran kerja karyawan. Ruangan yang sempit akan mengakibatkan lalulintas di tempat kerja menjadi semrawut, sehingga akan kehilangan semangat 
dalam bekerja. Instansi yang memiliki ruang kerja belum tentu mampu meningkatkan gairah para pegawainya, karena tanpa tata ruang yang baik akan menghambat proses kerja.

6) Keamanan

Rasa aman sangat berpengaruh terhadap semangat kerja dan kinerja.Di sini yang dimaksud dengan keamanan yaitu keamanan yang dapat dimasukkan ke dalam lingkungan kerja fisik. Jika di tempat kerja tidak aman guru tersebut akan menjadi gelisah, tidak bisa berkonsentrasi dengan pekerjaannya serta semangat kerja karyawan tersebut akan mengalami penurunan. Oleh karena itu sebaiknya suatu organisasi terus berusaha untuk menciptakan dan mempertahankan suatu keadaan dan suasana aman tersebut sehingga karyawan merasa senang dan nyaman dalam bekerja.

7) Kebersihan

Lingkungan kerja yang bersih akan menciptakan keadaan disekitarnya menjadi sehat. Oleh karena itu setiap organisasi hendaknya selalu menjaga kebersihan lingkungan kerja. Dengan adanya lingkungan yang bersih guruakan merasa senang sehingga kinerjanya akan meningkat.

Indikator-indikator lain terkait Lingkungan kerja menurut Nitissemito (1992:159) terdiri dari sebagai berikut :
1) Suasana Kerja

Suasana kerja adalah kondisi yang ada disekitar karyawan yang sedang melakukan pekerjaan yang dapat mempengaruhi pelaksanaan pekerjaan itu sendiri.

2) Hubungan dengan rekan kerja

Hubungan dengan rekan kerja yaitu hubungan dengan rekan kerja harmonis dan tanpa ada saling intrik diantara sesama rekan kerja.Hubungan yang harmonis dan kekeluargaan merupakan salah satu faktor yang dapat memengaruhi kinerja seseorang.

3) Tersedianya Fasilitas untuk Karyawan

Hal ini dimaksudkan bahwa peralatan yang digunakan untuk mendukung kelancaran kerja lengkap / mutakhir. Tersedianya fasilitas kerja yang lengkap, walaupun tidak baru merupakan salah satu penunjang proses dalam bekerja.

Jika lingkungan kerja mendukung maka akan timbul keinginan pegawai untuk melaksanakan tugas dan tanggung jawabnya. Keinginan ini kemudian akan menimbulkan persepsi pegawai dan kreativitas pegawai yang diwujudkan dalam bentuk tindakan. Persepsi pegawai juga dipengaruhi oleh factor intensif yang diberikan oleh instansi.

\section{Kinerja Guru}

Istilah kinerja berasal dari job performance, yang berarti prestasi kerja atau 
prestasi sesungguhnya yang dicapai seseorang. Pengertian Kinerja adalah hasil kerja secara kualitas dan kuantitas yang dicapai oleh seorang dalam melaksanakan tugasnya sesuai dengan tanggung jawab yang diberikan kepadanya (Anwar P. Mangkunegara: 2004). Kinerja merupakan suatu fungsi dari motivasi dan kemampuan. Untuk menyelesaikan tugas atau pekerjaan yang sepatutnya memiliki derajat kesediaan dan tingkat kemampuan tertentu. Kinerja merupakan perilaku nyata yang ditampilkan setiap orang sebagai prestasi kerja yang dihasilkan oleh pegawai sesuai dengan perannya dalam Organsasi (Veithzal Rivai:2004).

Dalam UU No. 20 Tahun 2003, Pasal 39 Ayat 2 tentang Guru merupakan tenaga profesional yang bertugas merencanakan dan melaksanakan proses pembelajaran, melakukan pembimbingan dan pelatihan, serta melakukan penelitian dan pengabdian kepada masyarakat, terutama bagi pendidik pada perguruan tinggi. Dalam kaitannya dengan tugas guru sebagai pengajar, dalam prakteknya berkaitan erat dengan tugas membimbing, bahkan di dalamnya juga terselip tugas mendidik (Purwanto, 1996:99100).Perilaku guru ini berkaitan erat dengan pelaksanaan tugas mendidik, mengajar dan membimbing siswa, sebagaimana tertuang dalam Kep.Mendiknas RI No. 025/01/2005 tentang Petunjuk Teknis Ketentuan
Pelaksanaan Jabatan Fungsional Guru dan Angka Kredit.

Selanjutnya menurut Prawirosentono, (1999:236-239) mengungkapkan bahwa ada 3 faktor yang dapat mempengaruhi kinerjayaitu:

1) Efektifitas dan Efesiensi

Bila suatu tujuan tertentu akhirnya bisa dicapai, kita boleh mengatakan bahwa kegiatan tersebut efektif tetapi apabila akibat-akibat yang tidak dicari kegiatan menilai yang penting dari hasil yang dicapai sehingga mengakibatkan kepuasan walaupun efektif dinamakan tidak efesien.Sebaliknya, bila akibat yang dicari-cari tidak penting atau remeh maka kegiatan tersebut efesien.

2) Otoritas (wewenang)

Otoritas menurut adalah sifat dari suatu komunikasi atau perintah dalam suatu organisasi yang dimiliki seseorang anggota organisasi kepada anggota yang lain untuk melakukan suatu kegiatan kerja sesuai dengan kontribusinya. Perintah tersebut mengatakan apa yang boleh dilakukan dan yang tidak boleh dalam organisasi tersebut.

3) Disiplin

Disiplin adalah taat kepada hukum dan peraturan yang berlaku.Jadi, disiplin adalah kegiatan yang bersangkutan dalam menghormati perjanjian kerja dengan organisasi dimana dia bekerja. 
Berhasil tidaknya kinerja yang telah dicapai oleh organisasi tersebut di pengaruhi oleh tingkat kinerja secara individual maupun secara kelompok. Dengan asumsi semakin baik kinerja guru maka diharapkan kinerja sekolah/madrasah akan semakin baik. Kinerja guru dalam proses pembelajaran yang berkaitan dengan tugas utama seorang guru dalam Juknis Peraturan Menteri Pendidikan Nasional No. 35 (20:25), yang digunakan sebagai dasar penilaian kinerja guru adalah sebagai berikut :

1) Perencanaan program kegiatan pembelajaran

Tahap perencanaan pembelajaran adalah tahap yang berhubungan dengan kemampuan guru menguasai bahan ajar. Kemampuan guru dapat dilihat dari cara atau proses penyusunan program kegiatan pembelajaran yang dilakukan oleh tenaga pendidik, yaitu mengembangkan silabus dan rencana pelaksanaan pembelajaran (RPP).

2) Pelaksanaan Kegiatan Pembelajaran

Kegiatan pembelajaran dikelas adalah inti penyelenggaraan pendidikan yang ditandai oleh adanya kegiatan pengelolaan kelas, penggunaan media dan sumber belajar dan penggunaan metode serta strategi pembelajaran.

3) Evaluasi/Penilaian Pembelajaran

Penilaian hasil belajar adalah kegiatan atau cara yang ditunjukkan untuk mengetahui tercapai atau tidaknya tujuan pembelajaran dan juga proses pembelajaran yang telah dilakukan. Pada tahap ini seorang guru dituntut memiliki kemampuan dalam menentukan pendekatan dan cara-cara evaluasi, penyusunan alat evaluasi, pengolahan dan penggunaan hasil evaluasi.

\section{METODE PENELITIAN}

Jenis penelitian ini adalah penelitian Deskriptif Kausal. Menurut Santoso (2003:45) yang dimaksudkan dalam penelitian ini untuk mengangkat fakta, keadaan dan variable yang terjadi selama penelititan berlangsung dan menyajikan apa adanya tentang "Pengaruh Beban kerja, Stres Kerja dan Lingkungan Kerja Terhadap Kinerja Guru pada Madrasah Aliyah Negeri 2 Kota Palu.

Populasi yang ditetapkan dalam observasi ini adalah keseluruhan dari Guru PNSpada MAN 2 Kota Palu yang berjumlah 55 orang. Teknik pengambilan sampel dalam penelitian ini dilakukan dengan menggunakan teknik sensus dimana dari semua populasi yang ada dijadikan sampel dalam obervasi ini yaitu sebanyak 55 orang Guru PNS Man 2 Kota Palu.

Skala yang digunakan dalam penelitian ini adalah skala Likert. Menurut Kinnear (dalam Umar 2008 : 70) skala Likert ini berhubungan dengan pernyataan tentang sikap seseorang terhadap sesuatu, misalnya 
setuju-tidak setuju, senang-tidak senang, dan baik-tidak baik. Dengan skala Likert, maka variabel yang akan diukur dijabarkan indikator-indikatornya yang mana dalam pengukurannya respoden diberikan beberapa alternatif untuk memilih salah satu jawaban yang dianggap paling tepat. Adapun skala Likert yang digunakan terdiri dari lima pilihan jawaban yaitu sebagai berikut :

$\begin{array}{ll}- \text { Sangat Setuju (SS) } & =\text { Nilai } 5 \\ \text { - Setuju (S) } & =\text { Nilai } 4 \\ \text { - Ragu-ragu (RR) } & =\text { NIlai } 3 \\ \text { - Tidak Setuju (TS) } & =\text { Nilai } 2 \\ \text { - Sangat Tidak Setuju } & =\text { Nilai } 1\end{array}$

Sebelum penelitian tersebut dilaksanakan, dilakukan pengujian validitas dan reliabilitas pada instrument penelitian.

Teknis analisis data menggunakan :

- Uji asumsi klasik yang terdiri dari uji multikolinearitas, uji heterokedastisitas, dan uji normalitas.

- Analisis regresi linear berganda Analisis ini digunakan untuk mengetahui pengaruh masing-masing variabel bebas terhadap variabel terikat.

- Uji F (F-test)

Uji-F, digunakan untuk mengetahui pengaruh signifikan secara simultan antara beban kerja, stres kerja dan lingkungan kerja terhadap kinerja guru MAN 2 Kota Palu. Untuk mengetahui keberartian dan koefesien regresi secara serempak digunakan uji-F, dengan bentuk formulasi menurut Ruslan dan Rosady (2004:13)

- Uji t (t-test)

Uji-t, digunakan untuk mengetahui pengaruh signifikan secara parsial antara variabel independen (beban kerja, stress kerja dan lingkungan kerja) terhadap variabel dependen (kinerja guru) MAN 2 Kota Palu.Untuk menguji pengaruh masing-masing variabel bebas secara parsial atau untuk mengetahui variabel mana yang relatif dominan berpengaruh terhadap variabel terikat $(\mathrm{Y})$ digunakan uji $\mathrm{t}$ (student test) dengan formulasi rumus menurut Ruslan dan Rosady, (2004:13)

- Uji R ${ }^{2}$ Koefisien Determinisasi

Uji ini digunakan untuk mengetahui tingkat keeratan hubungan antara variabel terikat. Dimana tidak ada ukuran yang pasti berapa besarnya $R^{2}$ untuk mengatakan bahwa suatu pilihan variabel sudah tepat. Jika $\mathrm{R}^{2}$ semakin besar atau mendekati 1, maka model makin tepat. Untuk data survai yang berarti bersifat cross section data yang diperoleh dari banyak responden pada waktu yang sama, maka nilai $\mathrm{R}^{2}=0,2$ atau 0,3 sudah cukup baik karena sebagian besar varians dan variabel dapat menjelaskan varian dari variabel bebas dapaat menjelaskan varians dari varaibel terikat. 


\section{HASIL DAN PEMBAHASAN}

Berdasarkan hasil uji Anova (Analisys of Varians) atau $\mathrm{F}$ test dengan menggunakan tingkat kepercayaan 95\% dan alfa 5\% df 3 variabel (n-k-1) atau (55-3-1) dimana $n=$ jumlah responden, $\mathrm{k}=$ jumlah variabel independen. Diperoleh nilai $F_{\text {hitung }}$ sebesar 5,023> $F_{\text {tabel }} 2,79(5,023>2,79)$ maka HO ditolak. Artinya ada pengaruh secara signifikan antara variabel beban kerja, stress kerja dan lingkungan kerja secara bersamasama terhadap kinerja guru. Dengan demikian hasil ini dapat disimpulkan bahwa variabel beban kerja, stress kerja dan lingkungan kerja secara simultan berpengaruh terhadap kinerja guru MAN 2 Kota Palu (Y), sehingga hipotesis pertama yang diajukan dapat diterima. Hal ini bermakna jika beban kerja, stress kerja dan lingkungan kerja terjadi secara bersamaan maka akan berpengaruh terhadap kinerja guru MAN 2 Kota Palu.

\section{Hasil Pengujian Uji $t$}

Untuk variabel beban kerja diperoleh nilai $t_{\text {hitung }}$ sebesar $-2,316>t_{\text {tabel }}-1,675$, maka Ho ditolak, artinya ada pengaruh secara signifikan variabel beban kerja terhadap kinerja guru. Pengaruh yang dihasilkan bersifat negatif, dengan nilai ini memberikan makna bahwa secara parsial variabel beban kerja memberikan pengaruh secara negatif dan signifikan terhadap kinerja guru MAN 2 Kota Palu. Hal ini bermakna bila beban kerjatidak seimbang maka kinerja guru akan menurun. Sementara untuk nilai koefisien determinasi parsial $\left(\mathrm{r}^{2}\right)$ adalah sebesar 0,309 atau sebesar 30,9\%. Hal ini menunjukkan bahwa secara parsial variabel beban kerja mempunyai pengaruh sebesar 30,9\% terhadap kinerja guru MAN 2 Kota Palu. Dengan demikian melihat dari hasil tersebut maka hipotesis kedua yang menyatakan bahwa variabel beban kerja mempunyai pengaruh terhadap kinerja guru MAN 2 Kota Palu diterima. Dengan kata lain menerima hipotesis alternatif (Hi) dan menolak mulamula (Ho).

Untuk variabel stres kerja diperoleh nilai thitung sebesar 2,587> $t_{\text {tabel }} 1,675$, maka Ho ditolak, artinya ada pengaruh secara signifikan variabel stres kerja terhadap kinerja. Pengaruh yang dihasilkan bersifat positif, dengan nilai ini memberikan makna bahwa secara parsial variabel stres kerja memberikan pengaruh secara positif dan signifikan terhadap kinerja guru MAN 2 Kota Palu. Hal ini bermakna bila terjadi stres kerja maka akan meningkatkan kinerja serta akan memotivasi guru untuk berprestasi dalam bekerja. Sementara untuk nilai koefisien determinasi parsial $\left(\mathrm{r}^{2}\right)$ adalah sebesar 0,341 atau sebesar $34,1 \%$. Hal ini menunjukkan bahwa secara parsial variabel stres kerja mempunyai pengaruh sebesar $34,1 \%$ terhadap kinerja guru MAN 2 Kota Palu. Dengan demikian melihat dari hasil 
tersebut maka hipotesis kedua yang menyatakan bahwa variabel stres kerja mempunyai pengaruh terhadap kinerja guru MAN 2 Kota Palu diterima. Dengan kata lain menerima (Hi) dan menolak (Ho).

Untuk variabel lingkungan kerja diperoleh nilai $t_{\text {hitung }}$ sebesar 2,205> $t_{\text {tabel }}$ 1,675, maka Ho ditolak, artinya ada pengaruh secara signifikan variabel lingkungan kerja terhadap kinerja guru. Pengaruh yang dihasilkan bersifat positif, dengan nilai ini memberikan makna bahwa secara parsial variabel lingkungan kerja memberikan pengaruh secara positif dan signifikan terhadap kinerja guru MAN 2 Kota Palu. Hal ini bermakna bila lingkungan kerja memadai maka akan meningkatakan kinerja guru.Sementara untuk nilai koefisien determinasi parsial $\left(r^{2}\right)$ adalah sebesar 0,295 atau sebesar 29,5\%. Hal ini menunjukkan bahwa secara parsial variabel stres individu mempunyai pengaruh sebesar 29,5\% terhadap kinerja pegawai MAN 2 Kota Palu. Dengan demikian melihat dari hasil tersebut maka hipotesis kedua yang menyatakan bahwa variabel stres organisasi mempunyai pengaruh terhadap kinerja pegawai MAN 2 Kota Palu diterima. Dengan kata lain menerima (Hi) dan menolak (Ho).

\section{Regresi Linear Berganda}

Berdasarkan hasil analisis regresi linear berganda diperoleh instisari hasil-hasil penelitian dari tanggapan 55 orang yang dijadikan sebagai responden sehubungan dengan pengaruh dari ketiga variabel beban kerja, stress kerja, lingkungan kerja terhadap kinerja guru MAN 2 Kota Palu dapat dilihat pada tabel berikut :

\begin{tabular}{|c|c|c|c|c|}
\hline $\begin{array}{l}\text { Faktor- } \\
\text { faktor }\end{array}$ & $\begin{array}{c}\text { Koefisien } \\
\text { Regresi } \\
\text { (B) }\end{array}$ & t-hitung & Sig & $\begin{array}{l}\text { Parsial } \\
\text { (r) }\end{array}$ \\
\hline 1 & 2 & 3 & 4 & 5 \\
\hline Beban Kerja & $-0,184$ & $-2,316$ & 0,025 & $-0,309$ \\
\hline Stres Kerja & 0,218 & 2,587 & 0,013 & 0,341 \\
\hline $\begin{array}{c}\text { Lingkungan } \\
\text { Kerja }\end{array}$ & 0,217 & 2,205 & 0,032 & 0,295 \\
\hline \multicolumn{5}{|c|}{ Multiple-R 0,778} \\
\hline \multicolumn{2}{|c|}{ R Square 0,572} & F-tabel & \multicolumn{2}{|c|}{2,79} \\
\hline \multicolumn{2}{|c|}{ Constanta 15,931} & \multicolumn{3}{|c|}{ F-hitung 5,023 } \\
\hline \multicolumn{2}{|c|}{ Alfa $\quad 0,05$} & \multicolumn{2}{|c|}{ t-tabel } & 1,675 \\
\hline
\end{tabular}

Berdasarkan hasil perhitungan diatas menunjukkan persamaan regresi yang dibangun dengan menggunakan nilai-nilai yang diperlukan sebagai berikut :

$$
Y=15,931-0,184 X_{1}+0,218 X_{2}+0,217 X_{3}
$$

\section{Koefisien Determinisasi}

Nilai Adjusted $R$ Square atau koefisien determinasi diperoleh sebesar 0,572. Nilai tersebut menunjukkan besarnya pengaruh variabel indenpenden secara keseluruhan (simultan) terhadap variabel dependen. Sehingga dapat diketahui secara keseluruhan (simultan) pengaruh variabel independen (beban kerja, stress kerja dan lingkungan kerja) terhadap variabel dependen (kinerja guru MAN 2 Kota Palu) dalam penelitian ini 
adalah sebesar $57,2 \%$ atau dapat diartikan bahwa $57,2 \%$ variasi dari variabel dependen dapat dijelaskan oleh variasi dari masingmasing variabel independen. Sedangkan sisanya $\quad(100 \%-57,2 \%) \quad$ sebesar $\quad 42,8 \%$ dijelaskan oleh variabel lain diluar dari model yang sudah ada.

\section{PEMBAHASAN HASIL PENELITIAN}

Pengaruh Beban Kerja, Stres Kerja dan Lingkungan Kerja Terhadap Kinerja Guru Madrasah Aliyah Negeri 2 Kota Palu

Hasil pengujian secara simultan telah membuktikan bahwa variabel beban kerja (X1), stres kerja (X2) dan lingkungan kerja (X3) berpengaruh signifikan terhadap kinerja guru MAN 2 Kota Palu.

Pengaruh Beban Kerja terhadap Kinerja Guru Madrasah Aliyah Negeri 2 Kota Palu

Nilai t-hitung variabel beban kerja atau nilai probabilitanya memberikan makna bahawa secara parsial beban kerja berpengaruh negatif dan signifikan terhadap kinerja guru MAN 2 Kota Palu. Ditemukan pengaruh negatif dan signifikan beban kerja terhadap kinerja guru MAN 2 Kota Palu, yang menandakan bahwa beban kerja yang dirasakan oleh sebagian guru di MAN 2 Kota Palu dalam menjalankan tugastugasnnya disekolah cukup tinggi sehingga memberikan pengaruh negatif dan signifikan terhadap kinerja guru. Hal ini sesuai dengan hasil penelitian dan wawancara penulis yang menunjukkan sebuah kondisi riil bahwa sebagian guru di MAN 2 Kota Palu mengalami kelelahan disebabkan karena tingginya beban kerja guru dalam tugasnya.Kondisi ini terjadi disebabkan karena volume tugas yang harus dikerjakan guru melebihi batas kemampuannya.Dimana sebagian guru di MAN 2 Kota Palu memiliki peran Ganda sebagai tenaga pengajar, wali kelas dan pembina untuk berbagai jenis kegiatan yang ada disekolah.Belum lagi guru yang memiliki jabatan seperti kepala madrasah, wakil kepala madrasah tentunya guru yang memiliki jabatan tersebut mendapatkan tugas tambahan diluar dari tupoksi utamanya yakni mengajar, sehingga cenderung kurang efisien dan efektif dalam bekerja sehingga kondisi ini harus diatasi.

Lebih lanjut lagi dijelaskan bahwa beban kerja yang cukup tinggi menyebabkan berkurangnya kesempatan sebagian guru di MAN 2 Kota Palu mempersiapkan materi mengajarnya, mempersiapkan metode dan media untuk pengajaran. Selain itu beban kerja yang tinggi juga menyebabkan berkurangnya waktu sebagian guru yang biasa dipakai dalam meningkatkan kemampuan dan pengetahuan individunya, seperti kemampuan menguasai materi, waktu untuk mempersiapkan dan melaksanakan proses pembelajaran pada peserta didik. Beban kerja yang tinggi juga menyebabkan 
kurangnya waktu yang dipakai sebagian guru dalam mendapatkan informasi terkini, baik mengenai perkembangan teknologi pembelajaran, perkembangan teori dan metode terbaru dalam pembelajaran sesuai dengan bidang keilmuannya.

\section{Pengaruh Stres Kerja terhadap Kinerja} Guru Madrasah Aliyah Negeri 2 Kota Palu

Nilai t-hitung variabel stres kerja atau nilai probabilitanya memberikan makna bahwa secara parsial stres kerja berpengaruh positif dan signifikan terhadap kinerja guru MAN 2 Kota Palu.Ditemukan pengaruh positif dan signifikan stres kerja terhadap kinerja guru MAN 2 Kota Palu, menandakan bahwa sesuai dengan hasil penelitian sebagian guru di MAN 2 Kota Palu dalam melaksanakan perannya disekolah sebagai pengajar hanya mengalami stres ringan sehingga tidak menurunkan kinerja. Hal ini menggambarkan bahwa guru MAN 2 Kota Palu cenderung hanya mengalami stres kerja yang ringan sehingga termotivasi untuk berprestasi dalam bekerja.

Dalam sudut pandang guru yang mengalami stres ringan cenderung akan memberikan dampak positif, artinya guru didesak untuk melakukan tugas yang lebih baik sehingga tujuan organisasi dapat tercapai. Menurut peneliti, adanya dampak positif terhadap kinerja guru MAN 2 Kota Palu dikarenakan pembagian tugas dan peran tanggung jawab sudah terlaksana dengan baik serta terjalin dukungan sesama guru sehingga pekerjaan dapat diselesaikan sesuai waktunya. Hal ini juga terjadi dengan adanya organisasi yang jelas serta kondisi kerja yang baik dan beban kerja yang tidak berlebihan. Adanya peralatan dari guru yang rusak sehingga membuat guru tertekan. Tetapi karena adanya sikap tanggap dari organisasi maka peralatan yang rusak tadi segera diperbaiki sehingga membuat guru kembali bekerja lebih maksimal dalam menyelesaikan pekerjaan mereka.

Pengaruh Lingkungan Kerja terhadap Kinerja Guru Madrasah Aliyah Negeri 2 Kota Palu

Nilai t-hitung variabel lingkungan kerja atau nilai probabilitanya memberikan makna bahwa secara parsial lingkungan kerja berpengaruh positif dan signifikan terhadap kinerja guru MAN 2 Kota Palu. Ditemukan pengaruh positif dan signifikan lingkungan kerja terhadap kinerja guru MAN 2 Kota Palu bahwa dengan adanya lingkungan kerja yang baik maka akan meningkatkan kinerja guru dengan terbentukanya kualitas sumber daya manusia dalam organisasi, terciptanya kualitas kerja yang baik yang berdampak pada peningkatan hasil kerja organiasi tersebut.

Lingkungan kerja memberikan pengaruh positif dan signifikan terhadap kinerja guru MAN 2 Kota Palu.Hal ini memberikan makna terciptanya lingkungan 
yang kondusif dalam pelaksanaan tugas dan fungsi guru sehingga mendorong perbaikan dan peningkatan kinerja.Hal ini sesuai dengan pernyataan (Sudarmanto, 2009) bahwa budaya kerja dapat menciptakan lingkungan kerja yang kondusif untuk perbaikan kinerja dan manajemen perubahan.Demikian halnya dengan hubungan dengan sesama guru terjalin lebih baik. Baiknya komunikasi ini ditandai dengan adanya rasa saling percaya untuk melaksanakan pekerjaan dengan baik, bekerja sama dalam pelaksanaan kegiatan untuk menciptakan suasana yang lebih baik kedepannya.

\section{KESIMPULAN}

Berdasarkan hasil pembahasan penelitian tersebut diatas, maka penulis dapat mengambil beberapa kesimpulan dari hasil penelitian ini sebagai berikut :

1. Beban Kerja, Stres Kerja dan Lingkungan Kerja secara simultan berpengaruh signifikan terhadap kinerja guru MAN 2 Kota Palu.

2. Beban Kerja (X1) berpengaruh negatif dan signifikan terhadap kinerja guru MAN 2 Kota Palu.

3. Stres Kerja (X2) berpengaruh positif dan signifikan terhadap kinerja guru MAN 2 Kota Palu.

4. Lingkungan Kerja (X3) berpengaruh positif dan signifikan terhadap kinerja guru MAN 2 Kota Palu.

\section{PENELITIAN KEDEPAN}

Berdasarkan pada analisis dan kesimpulan yang berkaitan dengan penelitian ini, adapun penelitian kedepan yang dianjurkan adalah :

1. Untuk variabel beban kerja, diharapkan kepada Pimpinan MAN 2 Kota Palu hendaknya memperhatikan beban kerja guru terkait kelebihan jumlah jam mengajar dan tugas tambahan karena dapat mengurangi kinerja guru yang bersangkutan

2. Untuk variabel stress kerja, diharapkan kepada Pimpinan MAN 2 Kota Palu untuk lebih memperhatikan tuntutan peran pada guru karena sesuai dengan hasil penelitian ditemukan fakta dilapangan bahwa terkadang guru lelah dengan adanya peran ganda sehingga dapat menyebabkan stress. Olehnya itu dalam menurunkan jumlah stress kerja perlu dilakukan kegiatan yang memotivasi seperti ESQ, rekreasi, out bond, waktu relaksasi, pembagian jam kerja, forum diskusi, kotak saran dan keterbukaan pimpinan yang pada akhirnya berimplikasi kepada kinerja guru yang optimal.

3. Untuk variabel lingkungan kerja, diharapkan kepada Pimpinan MAN 2 Palu agar memberikan perhatian ekstra kepada guru yang berada dilingkungan sekolah. Sebab kondisi lingkungan yang kotor, panas dan sarana prasarana yang kurang memadai dapat menyebabkan menurunnya kinerja guru.

4. Diharapkan kepada peneliti selanjutnya yang tertarik mengembangkan hasil penelitian ini agar mengamati variabel lain selain variabel penelitian ini karena sesuai dengan hasil penelitian ini turut 
pula memberikan pengaruh terhadap kinerja guru MAN 2 Kota Palu, sehingga kedepannya pengembangan dari hasil penelitian ini dapat lebih komprehensif

\section{DAFTAR PUSTAKA}

Effendi, 2002.Pengantar Ilmu Komunikasi. Jakarta. PT. Raja Grafindo

Husein Umar. 2008. Metode Penelitian untuk skripsi dan tesis bisnis. Jakarta. PT. Rajagrafindo Persada.

Mangkunegara, Anwar P. 2011. Manajemen Sumber Daya Manusia. Bandung. PT. Remaja Rosdakarya.

Nasution dan Rodhiah. 2008. Factor-faktor yang mempengaruhi Lingkungan Kerja. Jakarta. Jurnal Manajemen, Vol. 5: 1-17

Nitisemito, Alex S. 1991. Manajemen Sumber Daya Manusia, Jakarta. Ghalia Indonesia

PERMENDIKNAS No. 35. 2010. Petunjuk Teknis Pelaksanaan Jabatan Fungsional Guru dan Angka Kreditnya. Jakarta. Kementerian Pendidikan Indonesia.

Prawirosentono. 1999. Kebijakan Kinerja Pegawai. Yogyakarta. BPFE

Putra.2012.Pengaruh Beban Kerja terhadap Kepuasan Kerja dengan Stres Kerja Sebagai Variabel. Semarang. E-Jurnal Manajemen Unud, Vol. 3 No. 2:111117.

Rivai. 2008. Gejala-gejala stress. Jakarta. Salemba Empat.

Robbins, Steppen P. 2008. Perilaku Organisasi Edisi 12. Jakarta. Salemba Empat. lagi dalam menjelaskan variabel yang mempengaruhi kinerja guru di MAN 2 Kota Palu.

Sondang P. Siagian. 2008. Manajemen Sumber Daya Manusia, Jakarta. Asdi Mahasatya

Swasta, Basu. dan Sukotjo. 2004. Sumber daya Manusia. Salemba

Sedarmayanti. 2001. Manajemen sumber daya manusia. Jakarta. Pustaka Binaman Pressindo

Sudarmanto. 2009. Kinerja dan Pengembangan Kompetensi SDM. Yogyakarta. Pustaka Pelajar

Santoso.2003. Mengolah Data Statistik Secara Profesional.Edisi ke2.Jakarta.Elek Media Komputindo.

Undang-undang Republik Indonesia No. 20. 2003. Tentang Tenaga Pendidik

Undang-undang Republik Indonesia No. 14. 2005. Tentang Guru dan Dosen 